\title{
The Existence of Land Bank Institution in Supporting Land Procurement for National Development in Perspective of Indonesian Agrarian Law
}

\author{
Arnelli Darwita \\ Student of Doctoral Student, Faculty of Law, Jambi University, Indonesia 11 Jalan Dewi Sri, Kel. Tambak Sari, \\ Kec. Jambi Selatan, Kota Jambi 13639
}

\begin{abstract}
Land is a basic human need for a place to live and earn a living for human life. Population growth is getting higher day by day while land for housing is static so that land is increasing in price, this is a problem that must be solved. The state in carrying out national development also needs land for physical development such as infrastructure facilities, roads, bridges, hospitals, dams and others.

In the realization of land acquisition for national development, land conflicts often occur between the Government and Land Owners and even go to court. The government in various ways is looking for a way out for land acquisition for development to minimize agrarian conflicts and prepare land that is ready for use if needed for the public interest by establishing a Land Bank.

Land Acquisition for development for the public interest is regulated in Law No. 2 of 2012 with the technical regulation namely Government Regulation No. 71 of 2012. Several provisions in Law No. 2 of 2012 have been amended in Law No. 11 of 2020 concerning Job Creation as an Omnibus Law, which means the regulation made based on the compilation results or the result of combining several rules with different substances and levels and the technical regulation, whereas the Land Acquisition regulated in Article 136 until 148 of the Law and the technical regulation is The Government Regulation No. 19 of 2021.

The promulgation of Law Number 11 of 2020 which regulates the Land Bank is in the Article No 125 until 135 and followed orderly technical regulations, namely The Government Regulation No. 64 of 2021, is expected to be a solution for the Government to prepare land for development so that national development is not disturbed and minimizes land conflicts among the people, especially the people holding ownership rights to land. The implementation of the establishment of the Land Bank must be continuously monitored by all components of the community so that its implementation does not violate the laws and regulations and still refers to Article 33 paragraph (3) of the 1945 Constitution.
\end{abstract}

Keywords : land acquisition, land bank, public interest.

DOI: $10.7176 / \mathrm{JLPG} / 112-18$

Publication date:August $31^{\text {st }} 2021$

\section{Introduction}

The Preamble to the 1945 Constitution (Indonesian Constitution) mandates that the goal of the Republic of Indonesia is to protect the entire nation and the entire homeland of Indonesia, promote public welfare, educate the nation's life and participate in maintaining world order. Therefore, all sovereign states are basically obliged to be able to fulfil human rights for their citizens such as clothing, housing, decent work, sufficient food and a healthy environment so that the state is required to protect and utilize its territory optimally for the benefit of the people.

Article 33 Paragraph (3) of the 1945 Constitution states: "Earth, water and natural resources contained therein are controlled by the State and used for the greatest prosperity of the people". "controlled by the state" is emphasized as a public legal relationship as regulated in Article 2 paragraph (2) of Law No. 5 of 1960. The authority of the state's right to control is given details in the form of activities:

1. regulate and administer the designation, use, supply and maintenance of earth, water and space;

2. determine and regulate legal relations between people and the earth, water, and space;

Land Acquisition for development for the public interest is a necessity of a sovereign state to advance the development of its nation in all fields of state and national life. In carrying out the land acquisition, the Government often encounters obstacles because there is often a mismatch between the requests from those entitled to the land and the government that will use the rights. To overcome this problem, it was overviewed the establishment of a Land Bank to anticipate the need for land for national physical development.

In Law No. 5 of 1960 concerning Basic Agrarian Law, Article 6 states that all land rights have social functions. This means a person/a legal entity who owns their own land, whenever the state requires the land for a larger public interest, the holder of the land rights must surrender the land and any object on the land to the state with compensation.

Land Bank concept basically collects land from the community, especially abandoned and unused state land, 
then the land is collected, developed and redistributed according to the land use plan. The Land Bank is also a means of land management in the context of utilizing and using land to be more productive by obtaining land before there is a need, so that land prices are still cheap. Thus, a land bank is a systematic acquisition of land (land acquisition) that has not been developed, abandoned or left vacant land, the existence of a Land Bank is considered in the Land Acquisition for Development.

From a practical perspective, the existence of a land bank will help the government be more flexible to fulfil its legal obligations, such as providing housing, for the people concretely. This is the most important part of fulfilling the people's primary needs which are always full of various problems. Whenever the need is so urgent, the available land can be assessed and submitted through an independent and professional body. Not being intruded by various other interests, especially political interests that always accompany various public sectors. The concept of the Land Bank will practically facilitate the government in planning priority of housing programs for the people as mentioned. Of course, the practical implication is that people will feel protected when they need housing that will serve as shelter. The implications will also be very broad, up to the end of improving the quality of life of the people. From a departmental perspective, currently the existing ministry of housing is still functional and does not act operationally, so there is no power when carrying out its own development. The existence of Land bank not only for housing programs but for wider plan of national development for public interests and facilitating investment.

\section{Problem Formulation}

1. How are land acquisition arrangements for development for the public interest in Indonesia.

2. How is the arrangement of the Land Bank to support land acquisition for national development according to the prevailing laws and regulations in Indonesia.

Reviewing and analyzing these regulations is very important to see how far these regulations will be applicable to the implementation which must not only meet legal certainty but also fulfil the community's sense of justice.

\section{Research Method}

It includes normative legal research, library research that takes data from primary legal materials, secondary legal materials and tertiary legal materials, where primary legal materials take a statutory approach, namely the applicable regulations on the topic under study, while the material secondary law is legal material that provides an explanation of primary legal material and tertiary legal material is legal material that provides an explanation of primary legal material and secondary legal material.

\section{Discussion}

\subsection{Land Acquisition for Development for the Public Interest.}

The revocation of land rights is regulated in Article 18 of the Basic Agrarian Law which states that for the public interest, including the interests of the nation and state as well as the common interests of the people, land rights can be revoked by providing appropriate compensation and in a manner regulated by law. The provisions of Article 18 of the Basic Agrarian Law are implemented by Law No. 20/1961. Then as implementing regulations, the issuance of Government Regulation No. 39/1973 and Presidential Instruction No. 9/1973. The provisions regarding the revocation of land rights are stated in Article 1 of Law 20/1961 which states that: "in the public interest, including the interests of the nation and state as well as the interests of the nation and state as well as the common interests of the people, as well as the interests of development, then after hearing the Minister of Agrarian Affairs, the Minister of Justice and the Minister concerned, The President may revoke the rights to the land and the objects on it.

Land acquisition by the government through deliberation with the provision of compensation to holders of land rights, was first regulated in the Minister of Home Affairs Regulation No. 15 of 1975 concerning Provisions on Procedures for Land Acquisition. With the receipt of compensation, the holder of land rights relinquishes their land rights with the consequence that the land rights are erased so that the land becomes state land. The government agency that frees the land applies for a right to land on which public interest facilities will be built.

In summary, it can be concluded that efforts to acquire land for the public interest must be pursued through deliberation with land rights holders. However, if all efforts to reach deliberations fail while the public interest requires the availability of the land in question whose location cannot be moved, the method taken is the revocation of land rights.

Various excesses in the land acquisition process, among others: (1) the problem of the implementation of deliberation which is often fictitious; (2) the amount/amount of compensation is too small but it must be accepted; (3) deduction of the amount of compensation; and (4) various non-compliance with other administrative processes.

Land acquisition is also featured in Presidential Decree No. 55 of 1993. Article 1 number (1) states that land 
acquisition is "any activity to acquire land by providing compensation to those entitled to the land." The definition in this article is the understanding in a general sense, anyone who wants to get the land can also be categorized in terms of land acquisition, so it can be understood when the title of the Presidential Decree is written "land acquisition for the implementation of development for the public interest", in this case there are specifics that are emphasized which is the purpose and objective of the implementation in the land acquisition activities.

In 2005, Presidential Regulation No. 36 of 2005 was issued with the consideration that the land acquisition process was slow according to the previous Presidential Decree. This can be observed in the preamble of the Presidential Regulation, especially in the sentence "the need for land acquisition to be carried out quickly and transparently" with proper attention to respect for legal rights to land.

In a further development, when the country was increasingly open to domestic and foreign investors to participate in infrastructure development, as a follow-up to the Government's promises when the Infrastructure Summit took place in Jakarta on January 17-18, 2005, Presidential Decree No. 36 of 2005 was issued on 3 January 2005. May 2005.

Since the private sector have cooperated with the Government for infrastructure development, it is natural that in Presidential Decree No. 36 of 2005 had two criteria for public interest in the Presidential Decree are abolished, i.e. there is no requirement that the development activity "will" be owned by the Government. This can be understood because if the private sectors becomes the Government's partners in infrastructure development and if the cooperation is pursued through BOT (Build Operate Transfer) \& KerjaSama Operasional (In Indonesian $=\mathrm{KSO}$ ) or (joint venture or joint operation) the ownership will only be comeback to Indonesian the Government after the BOT/KSO period ends.

The Law No. 11 of 2020 which has amended, deleted, or stipulates new arrangements for several provisions in Law No. 2 of 2012 namely the provisions in Article 8, Article 10, Article 14, 19, Article 28, Article 34, Article 36, Article 42, Article 46. The technical regulation of this Law is The Government Regulations No. 19 of 2021 Concerning Land Acquisition Program for Development for Public Interest. Government Regulation No. 71 of 2012 as the technical government of The Law No. 2/2012 stated no more prevailing and be changed by Government Regulation No. 19 of 2021.

Many definitions of land acquisition have been made by academics and agrarian law expert. According to Law No. 2 of 2012 Article 1 paragraph (2) states that land acquisition is an activity to provide land by giving proper and fair compensation to the entitled party. The regulation on public interest is not explicitly stated in the Basic Agrarian Law, except for what is stipulated in Article 6 which states that all land rights have a social function. Furthermore, in General Elucidation II number 4, it is emphasized that the use of land must be adjusted to the situation and the nature of the rights, so that it is beneficial for the welfare of the rights holders as well as for the community and the State. Any land rights that exist in a person cannot be justified, that the land will be used (not used) solely for his personal interests. It was also emphasized that at the same time, this provision does not mean that individual interests will be totally suppressed by the public interest (society). The interests of society and individuals must balance each other, so that in the end the main goal will be achieved: prosperity, justice and the happiness of the people as a whole. These things, according to the Basic Agrarian Law, are characteristic of Indonesian national law, especially the Indonesian Basic Agrarian Basic Law which differs principally from the western legal system (Agrarische Wet), Domeinverklaaring and Onteigenings Ordonantie) which views private property rights absolutely.

In the Land Acquisition Law, Public Interest is defined as "the interest of the nation, state, and society that must be realized by the government and used as much as possible for the prosperity of the people."

The driving factors in land acquisition for the development of public interests include:

1. The principle of benefit, the use of the land acquisition project must be for the public interest without discriminating against class, degree and others. The most important factor in land acquisition for development must be the majority of the community.

2. The principle of compensation, in fact the state based on the power and authority it has in the management and control of land has the authority to control and regulate land designation, including land control for development in the public interest, although the state may not arbitrarily exercise its rights, provide compensation to the respective owners of land rights.

3. The principle of humanity means that it must provide protection and respect for human rights, the dignity and worth of every citizen affected by land acquisition for development proportionally.

4. The principle of justice means providing a guarantee of proper compensation to the entitled party, in order to get a better survival.

5. The principle of agreement means that the land acquisition process is carried out by deliberation between the parties without any element of coercion from any party.

Inhibiting factors in land acquisition for the public interest include :

a. public awareness of sacrificing their land for the public interest is still low, there are still groups of 
people who think that their land is absolute, anyone including the government has no right to challenge their land rights even though legally the land rights have a social function.

b. land prices are skyrocketing, especially for big city areas, higher land prices will affect the implementation of land acquisition, this is because land is not developing in urban areas, on the contrary

c. development continues to grow and the need for land continues to increase

d. It is difficult to find replacement land for victims who live in big cities to find a place to live due to the increasingly narrow.

For the issue of land acquisition for the public interest, in it an important process occurs, namely the termination of relations and rights from the owner for the public interest, which can only be done by the state as the holder of the right of controlling. The great power of the state here is limited by laws and regulations by containing the objectives of the public interest and a list of activities that are allowed for the state - the government - to terminate the rights of the owner.

Meanwhile, for the public interest, it is stated that there are 18 (eighteen) types of development activities categorized as public interest, including :

a. national defense and security;

b. public roads, toll roads, tunnels, railway lines, railway stations, and railway operating facilities;

c. reservoirs, dams, bending, irrigation, drainage and sanitation and other irrigation structures;

d. ports, airports and terminals;

e. oil, gas and geothermal infrastructure;

f. power generation, transmission, substation, network, and/or distribution;

g. government telecommunications and information networks;

h. places for waste disposal and processing;

i. central Government Hospitals or Regional Government Hospitals

j. public safety facilities;

k. public cemetery of the Central Government or Local Government;

1. social facilities, public facilities, and public green open spaces;

m. natural and cultural reserves;

n. central Government Office, Regional Government, or Village;

o. arrangement of urban slum settlements and/or consolidation of land and housing for low-income communities with rental status including for the construction of public houses and special houses;

p. educational infrastructure or schools of the Central Government or Local Government;

q. central Government or Regional Government sports infrastructure;

r. public markets and public parking lots;

s. upstream and downstream oil and gas industrial estates initiated and/or controlled by the central Government,

Regional Governments, State-Owned Enterprises, or Regional-Owned Enterprises.

t. special Economic Zones initiated and/or controlled by the Central Government, State Government, Regional

Owned Enterprises;

u. industrial estates initiated and/or controlled by the Central Government, Regional Governments, State-Owned

Enterprises, or Regional-Owned Enterprises;

v. tourism area initiated and/or controlled by the Central Government, Regional Government, State-Owned Enterprises, or Regional-Owned Enterprises;

w. food security areas initiated and/or controlled by the Central Government, Regional Governments, StateOwned Enterprises, Blood-owned Enterprises;

x. technology development area initiated and/or controlled by the Central Government, Regional Government, State-Owned Enterprises, Regional-Owned Enterprises.

Several cases of land acquisition for development in the public interest show that various problems have arisen in its implementation. The weaknesses in the previous laws and regulations relating to land acquisition for development in the public interest, with the enactment of Law No. 2 of 2012, the government tried to correct these deficiencies. Article 1 point 10 of Law No. 2 of 2012 provides an understanding of compensation, namely appropriate and fair compensation to the entitled party in the land acquisition process.

The assessment of the value of compensation by the Government is carried out field by field including : 1 . land; 2. above ground and underground space; 3 . buildings; 4. plants; 5 . objects related to land; and/or; 6. other losses that can be assessed. Other losses that can be assessed are non-physical losses that can be equivalent to the value of money, for example, losses due to loss of business or work, costs of moving places, costs of changing professions, and the value of residual property.

Compensation can be given in the form of: 1. money; 2. substitute land; 3. resettlement; 4. share ownership; 5. other forms agreed by both parties.

Resettlement is the process of providing replacement land to the rightful party to another location in accordance with the agreement in the land acquisition process. Meanwhile, Form of loss through share 
ownership is the participation of shares in development activities for the related public interest and/or management based on an agreement between the parties. Other forms agreed by both parties, for example a combination of 2 (two) or more forms of compensation.

In the context of land acquisition for the implementation of development in the public interest, many problems arise due to regulatory weaknesses. On the one hand, the existing regulations were not in the form of laws (regulations made by executive and judicative institutions) but regulations which were under the rank of the Laws namely Government Regulation, Presidential Decree, Minister Regulations, etc. On the other hand, the material aspect of all existing regulations is inadequate, so it has the potential to cause problems.

In the event that the Entitled Party refuses to for and/or the amount of Compensation based on results deliberation as referred to in Article 37, or the decision of the district court/Supreme Court as referred to in Article 38, Replace Losses are deposited in the local district court. (2) Custody of Compensation other than as referred to in paragraph (1), is also carried out on : a. The Eligible Party to receive Compensation does not its whereabouts are known; or b. Land Procurement Objects to be Replaced

Loss: 1. being the object of a case in court; 2 . ownership is still disputed;3. to be confiscated by the competent authority; or 4. become collateral in the bank. (3) The district court within a maximum period of 14 (fourteen) days must receive the deposit of Compensation as referred to in paragraph (1) and paragraph (2).

The problems that arise in land acquisition activities are more due to the provisions of the legislation in the land sector which do not provide good protection for holders of land rights. Especially regarding the compensation aspect, the existing regulations have not concretely guaranteed the lives of land rights holders to get a better life than before. The facts show that there is a process of impoverishment of land rights holders in every development project for the public interest. This is because regulations and their implementation in the field are still far from ideal, juridically, sociologically, and philosophically.

\subsection{Land Bank Existence}

Land Bank is a newly recognized institution in Indonesia and there are still many people who do not understand what and how the institution will work later because with the issuance of Law No. 11 of 2020 concerning Work Creation regulates Land Bank in the Article 125 until Article 135 and its technical regulations, Government Regulation No. 64 of 2021. Indonesia has only theregulations as the legal basis for establishing the Land Bank Institution but the institution has not yet been established.

The discourse regarding the establishment of a Land Bank in Indonesia began with a statement by the President of Indonesia to the State Minister of Agrarian Affairs/Head of the National Land Agency on August 12, 1993 as published in the national mass media the day after, the President requested that the idea of establishing a land bank be reviewed.

The urgency of implementing land management, among others, is triggered by the continued increase in the world's population, so that land that is static in nature must be able to provide the basic needs of its inhabitants. As an illustration of the rate of world population growth, we can see from World Bank data that the world population in 1963 was recorded at 3.195 billion people, increasing to 7.125 billion people in 2013. Meanwhile, another reference from Kompas.com which describes the rapid population growth is reported from the website. According to the United Nations, in 2011 the world's population reached 7 billion people. Then in 2016 it reached 7.4 billion people and the world population in 2020 reached 7.7 billion people. It is estimated that in 2030 it will grow to reach 8.5 billion people and in 2050 it will reach 9.7 billion people.

Responding to the world population explosion, today many European, American, African and Asian countries are implementing land banking as a means of land management. Land banking as an alternative to land management which is currently being implemented in many countries, is conceptually not a new thing. As a land management instrument, actually land banking/land bank is a form of refinement and expansion of land management patterns that were applied in several European countries several centuries ago when these countries carried out land consolidation programs, especially in the agricultural sector such as in the United Kingdom. 1710 - 1853), Denmark (1720), Sweden (1749), Norway (1821) and Germany (1821).

Initially, the concept of land consolidation was used in the agricultural sector, land banking as land management is usually applied in many countries for the purposes of consolidating land spatial plans, controlling land price fluctuations, streamlining land management, preventing non-optimal utilization and developing new urban planning. For this reason, the stakeholders in the land consolidation applied in the agricultural sector are generally the government sector, land banking the founders, can be either the government or the private sector.

In Indonesia, Article $28 \mathrm{H}$ Paragraph (4) of the 1945 Constitution stipulates that everyone has the right to have private property rights and such property rights may not be taken over arbitrarily by anyone. Although the 1945 Constitution after the amendment has given great attention and provided protection to individual rights, it does not mean that these rights are absolute because Article 6 of the Indonesia Basic Agrarian Law also stipulates that land rights have a social function which means that land rights that exist in a person cannot be justified by the absolute right holder of land. Therefore, Article 18 of the Basic Agrarian Law states that for the 
public interest including the interests of the nation and state as well as the common interests of the people, land rights can be revoked by providing appropriate compensation according to the provisions regulated by law. Thus, Law No. 20/1961 was born regarding the revocation of rights to land and objects on it.

Along with the demands of development, the need for land for development, whether carried out by the government or by the private sector has been increasing rapidly. This condition is exacerbated by the rapid growth rate of Indonesia's population and also the increasing needs of the population, which cannot be matched by the supply of land because the available land is static. This condition has very serious consequences for the pattern of the relationship between land and humans, and the relationship between humans and humans with the object of land.

Another problem that often occurs is the control of land by private companies on a large scale to be utilized in the future. Land reserves like this are actually a speculative practice and according to the laws and regulations are included in the category of land abandonment. Many of these practices are motivated by the mere profitseeking factor by obtaining the difference in the price of land when it was purchased and when it was resold (used) for a long period of time up to 10-20 years later by the parties involved in it.

Land conflicts become a national issue because of the high number and many obstacles in their resolution. The complex and unrelenting land conflicts nowadays have been caused by the weakness of regulations and the wrong application of land law so that in practice the interests of land rights holders are not protected certainly. The condition of political stability and very high government authority also causes agrarian problems to be neglected. It is not surprising that the idea of agrarian law reform is increasingly being discussed by many parties as a way of channeling the agrarian conflicts that have surfaced in the last three decades. One solution according to the government to find a way out of the increasing need for land for national development needs is to establish a land bank.

\subsection{Land Bank As One of Solutions in Supporting Land Acquisition for National Development}

The Indonesian Constitution has provided clear regulations regarding land in Indonesia. It is affirmed in Article 33 paragraph (3) of the 1945 Constitution of the Republic of Indonesia that the power granted to the earth, water and natural resources contained therein belongs to the state, and for that the state is obliged to regulate their ownership and lead their use. The aim is that all land in the entire sovereignty of the Indonesian nation is used for the greatest prosperity of the people.

Land has a very strategic function, both as a natural resource and as a space for development. However, in this vast country of Indonesia, there are still a lot of abandoned land whose use is not clear. This abandoned land tend to be used only as objects of speculation.

Therefore, the Central Government must immediately make improvements in the agrarian sector, especially related to land management for the development of public interests, social interests, development interests, economic equity, land consolidation, and agrarian reform. The government responds quickly and accurately in formulating policies to improve land governance problems. By implementing Law No. 11 of 2020 Concerning Job Creation, it is hoped that it will be able to face strategic environmental challenges and answer a number of problems and carry out the mandate of Article 33 paragraph (3) of the 1945 Constitution of the Republic of Indonesia, and provide a legal basis for land bank institutions in Indonesia as one of the efforts of agrarian reforms and improvement of land governance in Indonesia.

Land Bank is an important resource management tool to increase the productivity of land use. The method used in the land bank is market control and local market land stabilization. The land bank guarantees the availability of land for various development needs in the future, the efficiency of the State Revenue and Expenditure Budget/Regional Revenue and Expenditure Budget, reducing conflicts in the land acquisition process and reducing the adverse effects of land liberalization.

Land bank management is concerned with planning, organizing, implementing activities and supervising land bank activities in realizing the objectives of the land bank. Supported by adequate regulations and strong institutions, land bank management can ultimately realize the land bank function.

Regulations regarding Land Banks in the laws and regulations in Indonesia are known in Law Number 11 of 2020, Fourth Part, Land, paragraph 1, Land Banks from Article 125 to Article 135. The law is followed by The Government Regulation Number 64 of The 2021. Article 125 of Law Number 11 of 2020 stipulates : (1) the Central Government establishes a Land Bank Institution. (2) the Land Bank Institution as referred to in paragraph (1) is a special Institution that manages land. (3) the assets of the Land Bank are separated state assets. (4). the Land Bank Institution functions to carry out the planning, acquisition, utilization, and distribution of land. Meanwhile, Article 126 stipulates (1) the Land Bank Institution guarantees the availability of land in the framework of a just economy for: a. public interest; b. social interests; c. interests of national development; d. economic equity; e. land consolidation; and f. agrarian reform. As the technical regulation of Law No. 11 of the 2020 , The Government Regulation No. 64 of the 2021, Article 3 states that : Land bank functions : a. planning ; b. land getting ; c. land acquisition ; d. land management ; e. land use; and f. land distribution. (2). In realizing 
the functions as mentioned in verse 1, Land Bank has tasks as follows :

(1) a. planning long-term, medium-term, and annual activities, b. carry out land acquisition which can be sourced from the determination of the government and other parties; c. carry out land acquisition for development in the public interest or direct land acquisition; d. carry out land management from development, maintenance and security activities, and land control; e. carry out land use through utilization cooperation with other parties; and f. carry out land distribution by carrying out provision and distribution activities.

(2) In carrying out its duties, the Land Bank is transparent, accountable and non-profit (Article 4). The planning as referred to in Article 3 paragraph (1) letter a, includes: a. long-term plan; b. medium term plans; and c. annual plan. The long-term plan is an activity plan for a period of 25 years, while the medium-term plan is an activity plan for a period of 5 (five) years, while the annual plan is an activity plan for a period of 1 (one) year. The planning as mentioned above is based on the national mid-term development plan and the spatial plan determined by the head of the Executive Board after obtaining approval from the Committee.

(3) The acquisition of the land came from: a. land resulting from government stipulation; and/or b. land from the other side. Land as a result of government stipulation consists of state land originating from: a. ex-titled land; b. abandoned areas and lands; c. forest area release land; d. raised ground; e. reclaimed land; f. exmining land; g. land of small islands; h. land affected by the policy of spatial change; i. land that has no control over it.

Land from other parties comes from: a. Central government; b. Regional government; c. State-owned enterprises; d. Regional owned enterprises; e. business entity; f. legal entity ; and g. community while the acquisition of land from other parties is carried out through the following processes: a. purchase; b. receipt of grants/donations or the like; d. waiver of rights; and e. acquisition of other legal forms. Land development includes land preparation for the following activities: a. housing and residential areas; b. urban rejuvenation; c. integrated area development; d. land consolidation; e. construction of other facilities and infrastructure; f. construction of other facilities and infrastructure; g. land maturation to prepare land for land bank business management; and h. national strategic project.

Sources of wealth in the Land Bank can come from: a. State Revenue and Expenditure Budget; b. own income; c. state capital participation; and/or d. other legitimate sources in accordance with the provisions of the legislation.

The Land Bank structure consists of a Committee, Supervisory Board and Executive Board, which are tasked with setting strategic policies for the land bank. The Supervisory Board is in charge of supervising and providing advice to the Executive Body in carrying out activities for the operation of the land bank, while the Executive Body is responsible for the operation of the land bank for the interests and purposes of the land bank, as well as representing the land bank both inside and outside the court.

The committee consists of: the Minister as chairman and concurrently member, the Minister who carries out government affairs in the financial sector as a member, the Minister who carries out government affairs in the field of public works and public housing as a member; and/or Ministers/heads of other institutions appointed by the President as members. The chairman and members of the Committee are determined by Presidential Decree based on the proposal of the Minister and the provisions regarding the duties and procedures for determining the Committee are regulated in a Presidential Regulation. Meanwhile, the Supervisory Board is also determined by Presidential Decree, totaling a maximum of 7 (seven) people, its composition consists of 4 (four) people who come from professional elements and 3 (three) people who are chosen by the Central Government. Provisions regarding the election, determination, appointment and dismissal, duties, authorities, obligations, tenure, and procedures for making decisions of the Supervisory Board are regulated in a Presidential Regulation. The Executive Board consists of a Head and Deputies who are appointed by the chairman of the committee. The head and deputies are appointed and dismissed by the committee chairman, while the appointment and dismissal of the head and deputies can be proposed by the Supervisory Board.

Land managed by the Land Bank is granted by Management Rights in accordance with the provisions of the legislation. Land rights over Management Rights can be in the form of Cultivation Rights, Use Rights. This institution may transfer and/or use parts of the land with Management Rights to other third parties by agreement. The term of the Right to Build above the Management Right may be granted an extension of the term of the right and renewal of the right if it has been used and/or utilized in accordance with the purpose of granting the right, providing guarantees for the extension and renewal of the right over the Management Right in accordance with the requirements contained in the agreement. Extension and renewal of land rights on Management Rights can be granted at once after being used and agreed upon. In certain cases, the Land Bank may enter into a civil agreement for a more competitive period and the land rights may be encumbered with mortgage rights. To support operational activities, Land Banks may be granted Building Use Rights or Use Rights over Management Rights. The Minister shall supervise and control and/or the use and/or utilization of land above the Management Rights in accordance with the provisions of the laws and regulations. In the event that the Management Right on 
land has been properly utilized for housing for low-income communities, agriculture and/or plantations, for at least 10 (ten) years, it can be released to the community for ownership rights.

To carry out its duties, functions, and authorities, Bank Land is given a capital of Rp. 2,500,000,000,000.00 (two trillion five hundred billion rupiah). Capital can be provided in the form of cash, land, buildings and buildings, equipment and machinery, and/or other fixed assets. The additional capital can be given from the capitalization of the accumulated operating results of the Land Bank; and/or state capital participation. In the event that additional capital is required, the Committee proposes additional state capital participation to the Minister who carries out government affairs in the financial sector. The implementation of the provision of capital and additional state capital participation is carried out in accordance with the provisions of the legislation.

The Land Bank may apply for a loan in order to finance the capacity building for asset management as stated in the work plan and budget of the land bank which must be approved by the Committee and/or the Supervisory Board whose provisions will be further regulated by Presidential Decree. The Land Bank may write off non-land fixed assets from the books or balance sheet of the Land Bank. Further provisions regarding the write-off of non-land fixed assets are regulated by a Committee Regulation.

Furthermore, the preparation of the financial statements of the Land Bank is guided by financial accounting standards and the implementation of the Land Bank's accounting is carried out using the policies determined by the head of the Executive Board, while the audit of the financial reporting and accountability of the land bank operations is carried out by a public accountant who is selected by the Supervisory Board on a proposal to the Executive Board responsible for the implementation of the land bank. registered in the Audit Division. The Executive Board is required to prepare the land bank's annual report and submit it to the President through the Committee. Provisions regarding the procedures for preparing the land bank annual report, the accountability of the Executive Board and the Supervisory Board, as well as the ratification of the land bank annual report are regulated in a Presidential Regulation.

In general, Land Bank is intended as any government activity to provide land, which will be allocated for its use at a later date. Thus the land bank has function among others, as land collectors (land keeper) or land reserves, as land security for various development needs in the future (land warrantee), as land controller (land purchaser) and as land distribution for various development purposes (land distributors).

The Land Bank concept basically collects land from the community, especially abandoned and unused state land, then the land is collected, developed and redistributed according to the land use plan. So the Land Bank is also a means of land management in the context of utilizing and using land to be more productive by obtaining land before there is a need, so that land prices are still cheap. Thus, a Land Bank is a systematic land acquisition that has not been developed, abandoned land or that has been left vacant and is considered the

Existence of a Land Bank in land acquisition is potential for national development. Land acquisition by the government for the Land Bank is held for future use and in the context of implementing public land policies.

From a practical perspective, the existence of a land bank, the government will be more flexible when fulfilling legal obligations, namely providing housing, concretely to provide housing for the people. This is the most important part of fulfilling the people's primary needs which are always full of various problems. When the need is so urgent, the available lands can be assessed and submitted through an independent and professional body. Not being intruded by various other interests, especially political interests that always come into various public sectors.

Currently the concept of the Land Bank has practically facilitated the government in planning priority housing programs for the people as mentioned. The practical implication is that people will feel protected, when they need housing that will become a shelter. The implications will also be very broad, up to the end of improving the quality of life of the people. From a departmental perspective, currently the existing ministry of housing is still functional and does not act operationally, so there is no power when carrying out its own development. In this condition political interests shall be avoid, and the ministry must reflect on its program concretely.

Land Bank of course, will increase the provision of housing for the people by making a blueprint for people's housing as well as managing the Land Bank and carrying out development according to the expected priority scale. Such ideals make very sense to be applied, as part of the practical goal of providing affordable housing, water, and space; determine and regulate legal relations between people and legal actions concerning earth, water, space and in this regard, the implementing agency of the land bank should be in the form of a public legal entity. The Constitutional Court provides an interpretation of the state's right to control over the earth, water, space and natural resources contained therein by the State, namely: not in the sense that the state must own it, but the state only formulates policies (beleid), makes arrangements (regelendaad), manage (bestuurrdaad), manage (beheerdaad), and supervise (toezichthoudendaad). Public land banks that are oriented towards development for the public interest must also pay attention to the formulation and criteria of public interest in existing regulations. Development for the public interest basically aims to improve the general welfare and does not aim to seek profit. 
Apart from that, the so-called public interest concerns the interests of the nation and state, public services in the wider community, the people at large, and development. Talking about the public interest, it should be noted that not every government interest is always aimed at the public interest, such as port development, indeed it is in the government's interest, but not the public interest, because in the end it will be managed by Stated Owned Companies which is always oriented to seek profit for the benefit of the people, provide income to the state and the States Owned Enterprises themselves. On the other hand, this does not provide benefits to the wider community and the people. The forms of public interest activities still have to be explained about the extent to which the functions of the public interest will result from certain forms of public interest activities so that they are truly called public interests.

Based on Law No. 20 of 1961 concerning the revocation of land rights, defines the general interest broadly, among others, for the interests of the nation and state, the common interests of the people, and the interests of development. In the explanation of Law No. 20 of 1961, it is explained that public interest activities are not only limited to activities carried out by the government, but can also be carried out by the private sector as long as the activities are really in the public interest.

In Law No. 2 of 2012 concerning land acquisition for development in the public interest, it is stated that the public interest is the interest of the nation, state and society which must be realized by the government and used as much as possible for the prosperity of the people. Article 1 (6) of this Law, it can be concluded that the activity is really for the public interest which must contain 3 elements, namely:

1) the development activity is actually owned by the government. In this case, public interest activities cannot be owned by individuals or private parties. In other words, the private sector and individuals cannot have other types of public interest activities that require land acquisition, both private land and state land;

2) the development activities are carried out by the government. This element shows that the process of implementing and managing an activity for the public interest can only be played by the government;

3 ) the development activities are not for profit (non-profit). In this element it is stated that the function limit of an activity for the public interest is completely different from that of a private interest which aims to seek profit, so that the qualification of an activity is for an activity of the public interest if it is absolutely not allowed to seek profit.

From the description above, the presence of a public land bank institution can be a solution in the context of difficulties in special land acquisition.

This is for the public interest, because the public land bank institution functions as a land reserve institution that guarantees as well as ensures that development activities for the public interest are carried out effectively, efficiently, and sustainably. This is in accordance with one of the objectives of the land bank as a means of land management which ensures the availability of land for certain purposes. Several public interests that can be anticipated by public land banks : 1) land for relocation of communities affected by natural disasters, fires and conflicts; 2) land for urban development and settlement of low-income residents; 3) land getting ; 4) land bank for the city seat belt, i.e. the area around the city, water, and space; 4) determine and regulate legal relations between people and legal actions concerning earth, water, and space.

Public land banks that are oriented towards development for the public interest must also pay attention to the formulation and criteria of public interest in existing regulations. Development for the public interest basically aims to improve the general welfare and does not aim to seek profit or profit. Apart from that, the socalled public interest concerns the interests of the nation and state, public services in the wider community, the people at large, and development. Talking about the public interest, it should be noted that not every government interest is always aimed at the public interest, such as port development, indeed it is in the government's interest, but not the public interest, because in the end it will be managed by States Owned Enterprises which are always oriented to seek profit for the benefit of the people. provide income to the state and themselves. On the other hand, this does not provide benefits to the wider community and the people.

From the description above, the presence of a public land bank institution can be a solution in the context of difficulties in special land acquisition. This is for the public interest, because the public land bank institution functions as a land reserve institution that guarantees as well as ensures that development activities for the public interest are carried out effectively, efficiently, and sustainably. This is in accordance with one of the objectives of the land bank as a means of land management which ensures the availability of land for certain purposes. Several public interests that can be anticipated by public land banks, including: 1) Land for relocation of communities affected by natural disasters, fires and conflicts; 2) Land for urban development and settlement of low-income residents; 3) Land for land replacement for the owner/holder of land rights in land acquisition/land acquisition projects; 4) Land bank for the city seat belt, i.e. the area around the city water, and space;

Human resources who play a role in the land bank must have qualified and professional expertise so that the implementation of the land bank becomes efficient. Closing land acquisition in the implementation of development which always faces problems that cause physical development in all fields to stagnate or even adrift due to inadequate regulations and the shift in political economy from a populist economy to a capitalist economy 
neoliberalism makes land a commodity that triggers land and price liberalism the land soared due to the actions of land speculators. One of the breakthroughs to overcome the complexity of the problem of land acquisition for development purposes is the application of a land bank that functions as a land collector, as a land safeguard in order to secure the provision and designation and utilization of land according to the approved spatial plan. In addition, the function of the land bank is as a land controller, as a land appraiser who can suppress the emergence of land speculators and as a land distribution adapted to development programs and spatial plans which also functions to direct land use in urban development and a certain area.

Obstacles that will be faced in the implementation and institutional arrangement of land banks are that it requires a long period of time and very large capital, there must be supervision of value increases, the need for financial management and compensation for land owners with activities at the beginning, during the project and after it is carried out.

To succeed in implementing the land bank, the government is required to strengthen the role of regional planning institutions as the spearhead of regional development according to the mandate. The government must also strengthen the national land board and improve the quality of national land administration, especially in relation to land registration and land certification. A definite and firm spatial arrangement is also required for legal certainty regarding proof of ownership and control over land. A strong and authoritative national land board supported by firm and consistent law enforcement will ultimately prevent land conflicts related to overlapping ownership of land rights that have often occurred.

The concept of a land bank has potential to be applied in Indonesia in the form of a public land bank considering the provisions of article 33 paragraph 3 of the 1945 Constitution of the Republic of Indonesia and Article 2 of the Indonesia Basic Agrarian Law Number 5 of 1960, that the state has an important role in the implementation of the land bank.

\section{CONCLUSION :}

Indonesia as an archipelagic country has $5,193,250 \mathrm{~km}^{2}$ of sea and land area with a land area of 1,919,440 km while the ocean area is around $3,273,810 \mathrm{~km}^{2}$. With such a large area of the country, to this day, Indonesia is still in the process of completing and perfecting land data throughout Indonesia to minimize land conflicts faced in land acquisition because stakeholders still often have difficulty determining who has the right to land, how much and how much land. how much compensation is appropriate to be given

Land acquisition in supporting Indonesia's national development to uphold the principles of legal certainty and justice so that land conflicts can be minimized.

It is time for compensation to be replaced and enforced by compensation for profit so that it gives the impression that people who have rights to rights are not as oppressed by their own country but benefit in terms of proper compensation for their capital to live their lives elsewhere in the future.

The Land Bank whose existence is to support land acquisition for development must really be carried out as well as possible so that there is no impression that its existence is an order from certain parties, prioritizing abandoned state lands or abandoned lands to be managed and being exploited and taking privately owned land is the last option. The implementation of the land bank must be in accordance with the regional planning that has been determined both nationally and at the provincial and district levels.

Land confiscation/eviction as an effort by the government or private parties to acquire land is clearly contrary to the principles of the Basic Agrarian Law, because it is not based on any applicable statutory provisions. In order to achieve justice and to prevent the occurrence of impunity or property rights that can arise due to excessive legal protection, of course there is a need for legal restrictions on property rights on the said land.

Constitutionally, the protection of land rights has also been guaranteed by the Constitution, namely the first Article $28 \mathrm{H}$ paragraph (4) of the 1945 Constitution which states that "Everyone has the right to own private property and such property rights may not be taken arbitrarily by anyone. Article 6 of Basic Agrarian Law must be balanced in practice with Article $28 \mathrm{H}$ paragraph (4) of the 1945 Constitution. It may not be implemented arbitrarily by the government in power. The implementation of these programs (land acquisition for public interest and land banks) must be controlled well by the stakeholders and the Indonesian national interest must be the priority. The Indonesian Authority in any act of ruling shall be based on prevailing regulations and no let collusion with other parties for their group of business interests and benefit.

\section{References}

Adrian Sutedi, Implementation of Public Interest Principles in Land Procurement for Development, Sinar Graphic, Jakarta, 2020.

Aminudduin Salle, Land Procurement Law for Public Interest,Total Media,Jakarta, 2007

Boedi Harsono, Indonesian Agrarian Law, Trisaksi University, Jakarta, 2013.

Maria S.W. Sumardjono, Dynamics of Land Procurement Arrangements in Indonesia, GajahMaha, Yogyakarta, 
2017.

Muchsin, Indonesian Agrarian Law, Refika Aditama, 2010.

\section{Journals :}

Ranitya Ganindha, The Urgency of Establishing a Land Bank Institution As An Alternative For Providing Land For the Community For Public Interest, Legal Journal, 2016.

Tine Suartina, Legal Analysis of Land Acquisition Policy In The Public Interest in Indonesia, 2008, Society And Culture Journal, 2008.

\section{Constitution, Laws and Regulations :}

Constitution of 1945 of Indonesia

Law No.5 of 1960 Concerning Basic Agrarian Law

Law No. 20 of 1961 Concerning Regarding The Revocation of Rights To Land And Objects On It.

Presidential Decree No. 55 of 1993 Concerning Land Acquisition For Development In The Public Interest.

Presidential Regulation No. 36 of 2005 Concerning Land Acquisition For The Implementation Of Development In The Public Interest

Presidential Regulation No. 65 of 2006 Concerning Amendment To Presidential Regulation Number 36 of 2005 Regarding Land Acquisition For The implementation Of Development In The Public Interest

Law No. 2 of 2012 Concerning Land Acquisition For Development In The Public Interest.

Government Regulation No.71 of 2012 Concerning Land Procurement for Development for Public Interest.

Law No. 11 of 2020 Concerning Job Creation, Part of Land Acquisition For Development In The Public Interest.

Government Regulation No. 19 of 2020 Concerning Organizing Land Acquisition For Development In The Public Interest.

Government Regulation No. 64 of 2021 Concerning Land Bank Institution. 